\title{
Room Temperature Continuous-Wave Operation of GalnNAs Long Wavelength VCSELS
}

M.C. Larson, C.W. Coldren, S.G. Spruytte, H.E. Petersen, J.S. Harris

This article was submitted to $58^{\text {th }}$ Annual Device Research Conference, Denver, CO, June 19-21, 2000

Lawrence

June 22, 2000

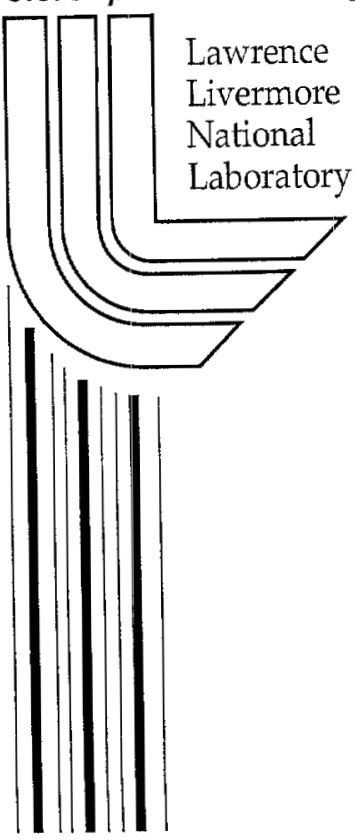




\section{DISCLAIMER}

This document was prepared as an account of work sponsored by an agency of the United States Government. Neither the United States Government nor the University of California nor any of their employees, makes any warranty, express or implied, or assumes any legal liability or responsibility for the accuracy, completeness, or usefulness of any information, apparatus, product, or process disclosed, or represents that its use would not infringe privately owned rights. Reference herein to any specific commercial product, process, or service by trade name, trademark, manufacturer, or otherwise, does not necessarily constitute or imply its endorsement, recommendation, or favoring by the United States Government or the University of California. The views and opinions of authors expressed herein do not necessarily state or reflect those of the United States Government or the University of California, and shall not be used for advertising or product endorsement purposes.

This is a preprint of a paper intended for publication in a journal or proceedings. Since changes may be made before publication, this preprint is made available with the understanding that it will not be cited or reproduced without the permission of the author.

This work was performed under the auspices of the United States Department of Energy by the University of California, Lawrence Livermore National Laboratory under contract No. W-7405-Eng-48.

This report has been reproduced directly from the best available copy.

Available electronically at http://Www.doc.gov/bridge

Available for a processing fee to U.S. Department of Energy

And its contractors in paper from

U.S. Department of Energy

Office of Scientific and Technical Information

P.O. Box 62

Oak Ridge, TN 37831-0062

Telephone: (865) 576-8401

Facsimile: (865) 576-5728

E-mail: reports@adonis.osti.gov

Available for the sale to the public from

U.S. Department of Commerce

National Technical Information Service

5285 Port Royal Road

Springfield, VA 22161

Telephone: (800) 553-6847

Facsimile: (703) 605-6900

E-mail: orders@ntis.fedworld.gov

Online ordering: http://www.ntis.gov/ordering.htm

OR

Lawrence Livermore National Laboratory

Technical Information. Department's Digital Library

http://www.llnl.gov/tid/Library.html 


\title{
Room temperature continuous-wave operation of GaInNAs long wavelength VCSELs
}

\author{
M.C. Larson ${ }^{1}$, C.W. Coldren ${ }^{1,2}$, S.G. Spruytte ${ }^{2}$, H.E. Petersen ${ }^{1}$, and J.S.Harris ${ }^{2}$ \\ ${ }^{1}$ Lawrence Livermore National Laboratory, P.O.Box 808, L-222, Livermore, CA 94551 \\ ${ }^{2}$ Solid State and Photonics Lab, Stanford University, CIS 126X, Via Ortega, Stanford, CA 94305
}

Vertical cavity surface-emitting lasers (VCSELs) are becoming increasingly important for short-haul optical fiber transmission systems. Given the commercial success of GaAs-based 850nm VCSELs, dramatic enhancements in transmission bandwidth and distance can be achieved in conventional singleand multi-mode fiber by extending the emission wavelength to the $1300 \mathrm{~nm}-1550 \mathrm{~nm}$ range. GaInNAs is a promising active layer material grown on GaAs that can achieve $1300 \mathrm{~nm}$ emission [1], and electrically pulsed broad-area GaInNAs VCSELs [2,3] have been realized. Here we take advantage of the properties of GaAs-based materials-thermally-conductive high contrast mirrors and AlAs-oxide current apertures-to demonstrate for the first time low-threshold $(\sim 1 \mathrm{~mA})$ GaInNAs VCSELs emitting at a wavelength of $1200 \mathrm{~nm}$ under continuous-wave room temperature operation.

The device structure is shown schematically in figure 1. The bottom mirror consists of a 22.5-period $\mathrm{n}$ doped GaAs/A1As distributed Bragg reflector (DBR) designed for a center wavelength $\lambda$ near $1200 \mathrm{~nm}$, the top mirror is a 22-period p-doped DBR whose reflectance is enhanced by a Ti/Au contact electrode, and the GaAs $\lambda$ cavity contains three $70 \AA \mathrm{Ga}_{0.3} \mathrm{In}_{0.7} \mathrm{~N}_{0.02} \mathrm{As}_{0.98}$ quantum wells (QWs) separated by $200 \AA$ $\mathrm{GaAs}$ barriers. The epilayers were grown by molecular beam epitaxy using solid-source arsenic and a rf nitrogen plasma source. After growth, the first 17 mirror periods of the top mirror were dry etched and subsequently capped with $\mathrm{SiO}_{2}$, and the remaining three periods were etched to expose the AlAs for lateral oxidation, which formed square unoxidized apertures as small as $3.6 \mu \mathrm{m}$ on a side. After the top contact metalization, devices were mounted without heat sinking on a glass slide for optical emission through the substrate, which was contacted electrically with indium solder.

The output power and voltage vs. injection current for a $5 \mu \mathrm{m} \times 5 \mu \mathrm{m}$ device operating $\mathrm{CW}$ at room temperature is shown in figure 2 . The threshold current is approximately $1.3 \mathrm{~mA}$, and the slope efficiency is 0.045 W/A. CW operation was possible in spite of an extremely high threshold voltage of $10.3 \mathrm{~V}$ which resulted from unoptimized doping and composition profiles at the heterointerfaces of the p-DBR. This created a large degree of self heating which limited the maximum output power to $0.080 \mathrm{~mW}$ at 3.8 $\mathrm{mA}$. Figure 3 shows emission spectra at threshold, with a lasing wavelength of $1201.54 \mathrm{~nm}$, and at 2.6 times threshold. The device lased in a single transverse and longitudinal mode, and far above threshold, the side mode suppression ratio was in excess of $40 \mathrm{~dB}$. As seen in figure 4 , the wavelength shifted with dissipated power at a rate of $0.0924 \mathrm{~nm} / \mathrm{mW}$. Given a wavelength shift with temperature of $0.0743 \mathrm{~nm} / \mathrm{K}$ obtained from broad area VCSELs [4], this indicates a calculated temperature rise of $\sim 60 \mathrm{~K}$ above the ambient at peak output power and a thermal impedance of $1.24 \mathrm{~K} / \mathrm{mW}$. CW laser operation also occurred for device sizes ranging from $3.6 \mu \mathrm{m}$ to $6.4 \mu \mathrm{m}$, with threshold currents from 0.94 to $2.3 \mathrm{~mA}$ and slope efficiency as high as 0.049 W/A.

In summary, we have demonstrated low-threshold GaInNAs VCSELs operating continuous-wave at room temperature, with an emission wavelength of $1200 \mathrm{~nm}$. Higher output power will be possible by reducing the resistance of the p-DBR, and $1300 \mathrm{~nm}$ emission should be achieved by increasing the indium and/or nitrogen content of the GaInNAs/GaAs multiple quantum well active layer. This work was performed under the auspices of the U.S. Department of Energy by University of California Lawrence Livermore National Laboratory under contract No. W-7405-Eng-48

[1] M. Kondow, et al., IEEE J. Selected Topics in Quantum Electronics 3, pp.719-730, 1997.

[2] M.C. Larson, et al., IEEE Photon. Technol. Lett. 10, pp. 188-190, 1998.

[3] C.W. Coldren, M.C. Larson, S.G. Spruytte, J.S. Harris, Electron. Lett., in press, 2000.

[4] C.W. Coldren, M.C. Larson, S.G. Spruytte, H.E. Garrett, J.S. Harris, CLEO ’00, 2000. 


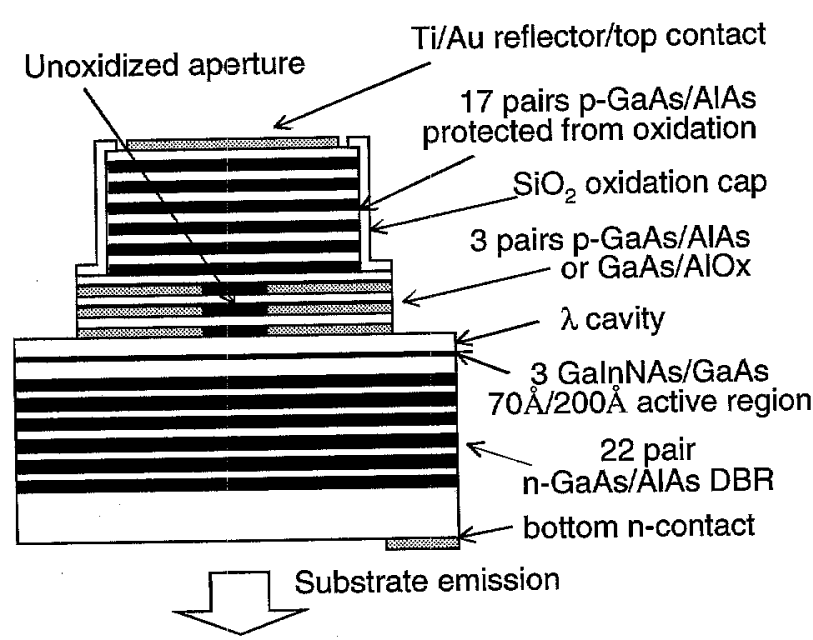

Fig. 1. Schematic diagram of GalnNAs vertical cavity laser.

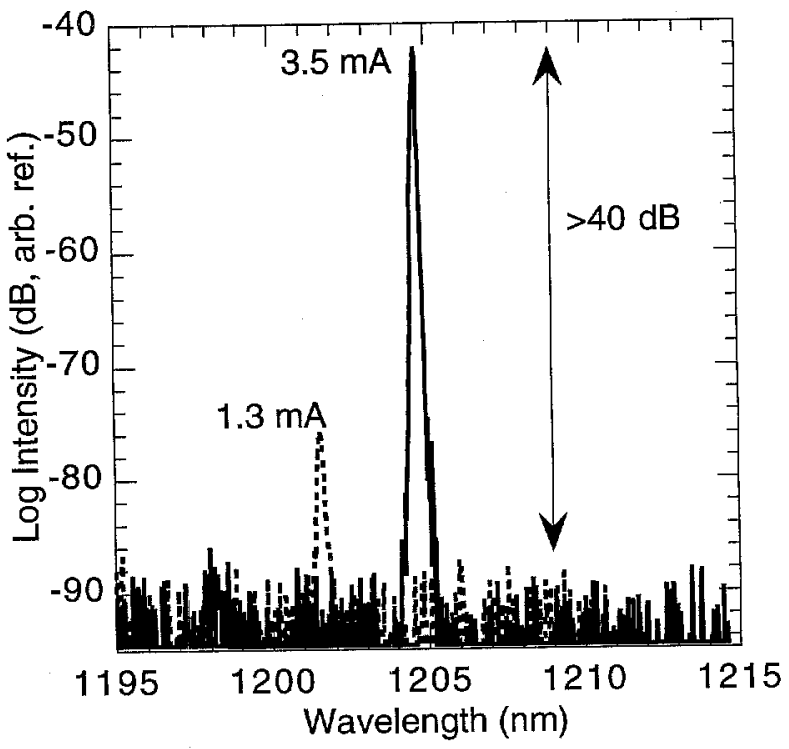

Fig. 3. Emission spectra at $1.3 \mathrm{~mA}\left(\sim \mathrm{I}_{\mathrm{th}}\right)$ and $3.5 \mathrm{~mA}\left(\sim 2.6 \mathrm{I}_{\mathrm{th}}\right)$.

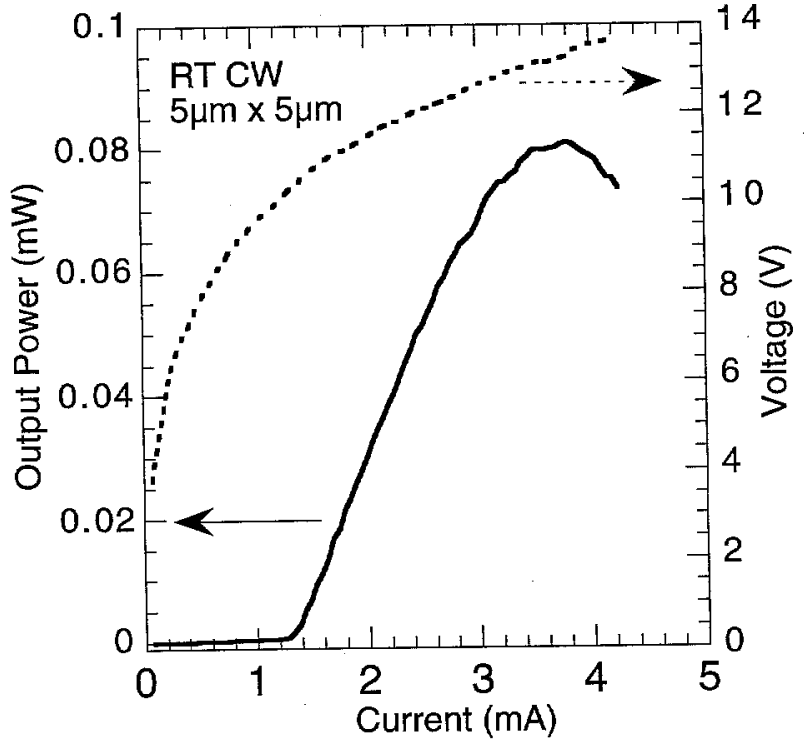

Fig. 2. Light output power and voltage vs. injection current.

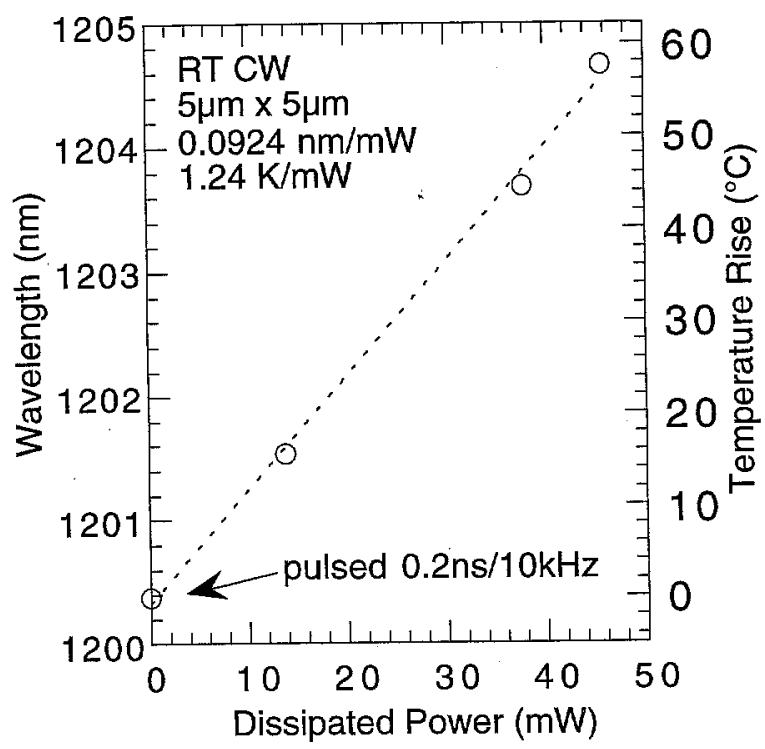

Fig. 4. Wavelength shift and corresponding calculated temperature rise vs. average dissipated power. The data point near the origin is obtained by pulsed measurement; the others are $\mathrm{CW}$. 